\title{
First record of Langdonia aristidae (Ustilaginales) from Madagascar
}

\section{Teodor T. Denchev ${ }^{1 *}$, Maria S. Vorontsova ${ }^{2}$ \& Cvetomir M. Denchev ${ }^{1}$}

\author{
${ }^{1}$ Institute of Biodiversity and Ecosystem Research, Bulgarian Academy of Sciences, 2 Gagarin St., 1113 \\ Sofia, Bulgaria \\ ${ }^{2}$ Royal Botanic Gardens Kew, Richmond, Surrey TW9 3AE, UK
}

Received 23 June 2015 / Accepted 28 June 2015 / Published 30 June 2015

Denchev, T.T., Vorontsova, M.S. \& Denchev, C.M. 2015. First record of Langdonia aristidae (Ustilaginales) from Madagascar. - Mycobiota 5: 15-20. doi: 10.12664/mycobiota.2015.05.03

\begin{abstract}
Langdonia aristidae is reported for the first time from Madagascar, on a new host plant, Aristida tenuissima.

Key words: Africa, Aristida, Langdonia aristidae, Madagascar, smut fungi, Sporisorium, taxonomy, Ustilaginales
\end{abstract}

\section{Introduction}

Aristida L. (three-awn grasses) is the largest genus of the family Poaceae subfamily Aristidoideae Caro (Kellogg 2015), with about 300 species distributed worldwide but mainly in tropical and warm-temperate regions. Members of this genus are common and often abundant in open environments, frequently found in habitats with a high level of disturbance such as burning. The lemma bears three awns which are fused at the base, a distinctive structure making Aristida easy to identify, which has previously been interpreted as a single awn with three branches at the apex; sometimes the lateral awns are reduced or suppressed (Henrard 1929-1932; Cerros-Tlatilpa et al. 2011).

Madagascar is home to an unusually high diversity of endemic species of Aristida and other members of the Aristidoideae (Besnard et al. 2014). Recently, a taxonomic treatment of Aristida tenuissima, a grass species endemic to Madagascar, was published by Vorontsova (2013), who noted that a tuft, mounted on the isolectotype sheet (in P), was infected with a smut fungus. Aristida tenuissima is a morphologically variable species in both habit and awn structure. Most collections have single geniculate awns, while the larger plants are

*Corresponding author: e-mail: ttdenchev@gmail.com 
more likely to have three awns (Vorontsova 2013). The inflorescences of the infected plant have aberrant inflated spikelets and reduced awns. The smut fungus was studied by us and identified as Langdonia aristidae.

The genus Langdonia was recently established for a monophyletic group of smut fungi on host plants belonging to Aristida (McTaggart et al. 2012b). The species of Langdonia possess sori that destroy all or some ovaries of an infected inflorescence. The sori are without columella and filled with spore balls formed from coiled sporogenous hyphae. Usually, sterile cells formed from non-sporogenous hyphae are absent (McTaggart et al. 2012a, b; Vánky 2013).

Langdonia comprises eight species, four of which are known from Africa: L. aristidae from Morocco and South Africa (as Sporisorium consanguineum (Ellis \& Everh.) Vánky), L. aristidicola (Speg.) McTaggart \& R.G. Shivas from Nigeria, Sudan, and Zambia, L. goniospora (Massee) McTaggart \& R.G. Shivas from Kenya, and L. inopinata (Vánky) McTaggart \& R.G. Shivas from Zambia and Zimbabwe (Vánky et al. 2011).

Langdonia aristidae is reported here as a new species for Madagascar.

\section{Material and methods}

A dried specimen from the herbarium of the National Museum of Natural History, Paris (P) was examined with a light microscope (LM) and scanning electron microscope (SEM). For LM observations and measurements, spore balls were mounted in lactoglycerol solution ( $\mathrm{w}: \mathrm{la}: \mathrm{gl}=1: 1: 2)$ on glass slides, gently heated to boiling point to rehydrate the spores, and then cooled. The measurements of spores are given in the form: min-max (mean \pm 1 standard deviation). For SEM, spore balls were attached to specimen holders by double-sided adhesive tape and coated with gold in an ion sputter. The surface structure of spores was observed and photographed at $10 \mathrm{kV}$ accelerating voltage using a JEOL JSM5510 scanning electron microscope. The description given below is based entirely on the specimen examined.

\section{Taxonomy}

Langdonia aristidae (Peck) McTaggart \& R.G. Shivas, in McTaggart et al., Persoonia 29: 130, 2012.

Figs I-7

Sori in the ovaries of all florets of the inflorescence, 1.5-2.5 $\times 0.2-0.4 \mathrm{~mm}$, fusiform, tapering at both ends, inconspicuous, completely concealed by the glumes and the lemma, covered by a persistent, thick, greenish brown peridium, enclosing the blackish brown, firmly agglutinated, granular mass of spore balls. Columella absent. Spore balls slightly irregular, subglobose, broadly ellipsoidal or ovoid, sometimes ellipsoidal, (35-)45$120(-138) \times(35-) 40-100(-127) \mu \mathrm{m}$, dark reddish brown, often opaque, composed of (tens-) hundreds, rather firmly united spores, that separate under pressure; covered by a layer of hyaline hyphae, the layer thicker in the younger spore balls. Immature spore balls hyaline, later yellowish brown, then light reddish brown. Sterile cells absent. Spores dimorphic, $(6-) 6.5-9(-10) \times(5-) 5.5-7.5(-8)(7.8 \pm 0.7 \times 6.6 \pm 0.6) \mu \mathrm{m}(\mathrm{n}=100)$, 


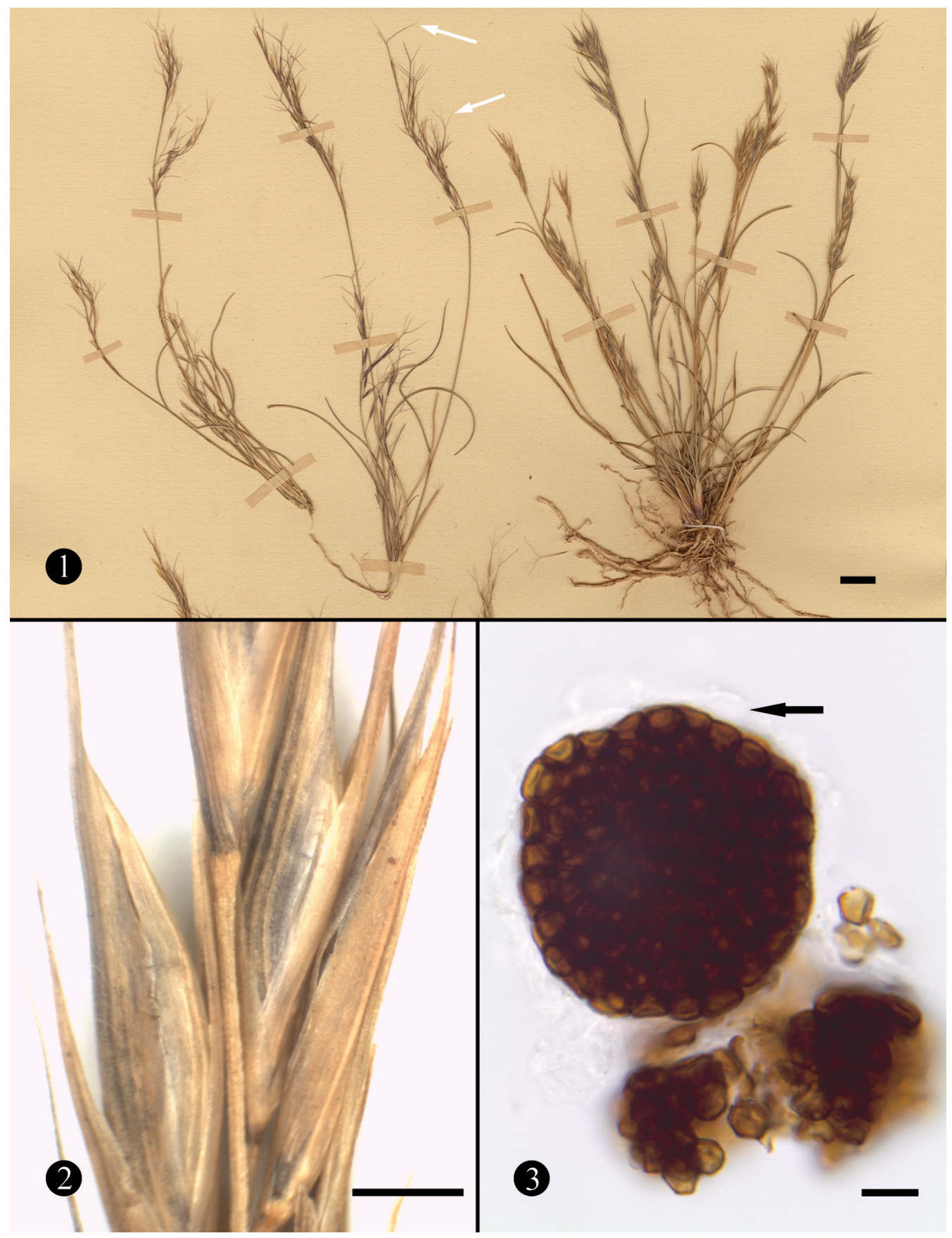

Figs 1-3. Langdonia aristidae in the ovaries of Aristida tenuissima (P 00446502). 1. Habit. To the right an infected plant with aberrant spikelets and reduced awns, to the left healthy plants with three-awned spikelets (arrows). 2. Habit. Inflated spikelets. 3. A spore ball covered by a layer of hyaline hyphae (arrow), in LM. Scale bars: $1=1 \mathrm{~cm}, 2=1 \mathrm{~mm}, 3=10 \mu \mathrm{m}$ 


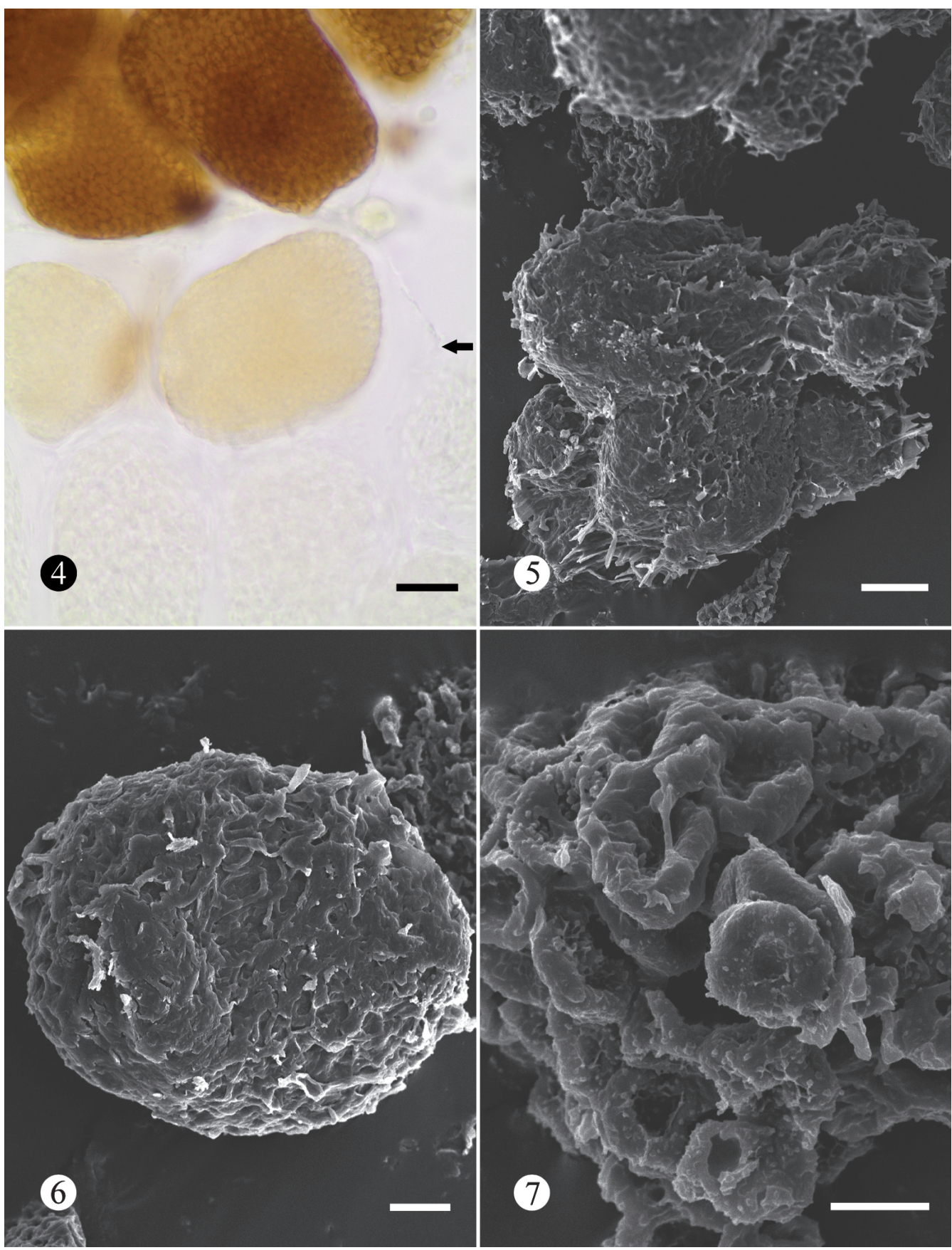

Figs 4-7. Langdonia aristidae on Aristida tenuissima (P 00446502). 4. Immature spore balls in LM, covered by a layer of hyaline hyphae (arrow). 5-7. Spore balls in SEM. Scale bars: $4=10 \mu \mathrm{m}, 5=20 \mu \mathrm{m}, 6=10 \mu \mathrm{m}, 7=5 \mu \mathrm{m}$ 
usually subpolyhedral, flattened on the contact sides, light to dark reddish brown. Outer spores verruculose on the free side, concave in the central part of the free surface, smooth on the contact sides, slightly darker than the inner spores. Inner spores smooth. Wall slightly uneven, $0.5-0.7(-0.8) \mu \mathrm{m}$ thick. In SEM the free surface of the outer spores minutely verruculose, warts up to $0.3 \mu \mathrm{m}$ high, sometimes fused in small groups.

Specimen examined - On Aristida tenuissima A. Camus: MADAGASCAR, FIANARANTSOA, Mont Belamboany, "pres du pelouse d'xerophiles", 1000 m, March 1912, leg. H. Perrier de la Bâthie, no. 10866 (P-00446502).

Distribution: on Aristida and Stipagrostis spp., in the tropics and subtropics of North and South America, Africa, Asia, and Australia (Vánky 2011; Vánky et al. 2011).

Comments. Langdonia aristidae is treated by Vánky (2011) in a broad sense, as a smut fungus found on 42 species of Aristida and three species of Stipagrostis.

Aristida tenuissima is endemic to Madagascar, distributed near streams and in waterlogged areas, on open rocky outcrops, at 1000-1700 m elevation in Antananarivo, Toamasina, Fianarantsoa, and Toliara provinces (cf. Vorontsova 2013, Fig. 2). During a taxonomic revision of the available herbarium specimens of $A$. tenuissima at $\mathrm{K}$, $\mathrm{P}$, and TAN, only one smut infected specimen, cited here, was found (Vorontsova 2013). Aristida tenuissima is a new host plant record for Langdonia aristidae.

Acknowledgements. The authors are grateful to Dr Roger G. Shivas (Biosecurity Queensland, Australia) for the helpful comments on the manuscript and to Curator of $\mathrm{P}$ for the examined specimen.

\section{References}

Besnard, G., Christin, P.A., Malé, P.J.G., Lhuillier, E., Lauzeral, C., Coissac, E. \& Vorontsova, M.S. 2014. From museums to genomics: old herbarium specimens shed light on a C3 to C4 transition. - Journal of Experimental Botany 65: 6711-6721. http://dx.doi.org/10.1093/jxb/eru395

Cerros-Tlatilpa, R., Columbus, J.T. \& Barker, N.P. 2011. Phylogenetic relationships of Aristida and relatives (Poaceae, Aristidoideae) based on noncoding chloroplast (trnL-F, rpl16) and nuclear (ITS) DNA sequences. - American Journal of Botany 98: 1868-1886. http://dx.doi.org/10.3732/ajb.1100103

Henrard, J.T. 1929-1932. A monograph of the genus Aristida. - Mededeelingen van 's Rijks-Herbarium 58: $1-325$.

Kellogg, E.A. 2015. Poaceae. - In: K. Kubitzki (ed.). The families and genera of vascular plants. Vol. 13. Springer, Berlin.

McTaggart, A.R., Shivas, R.G., Geering, A.D.W., Callaghan, B., Vánky, K. \& Scharaschkin, T. 2012a. Soral synapomorphies are significant for the systematics of the Ustilago-Sporisorium-Macalpinomyces complex (Ustilaginaceae). - Persoonia 29: 63-77. http://dx.doi.org/10.3767/003158512X660562

McTaggart, A.R., Shivas, R.G., Geering, A.D.W., Vánky, K. \& Scharaschkin, T. 2012b. Taxonomic revision of Ustilago, Sporisorium and Macalpinomyces. - Persoonia 29: 116-132. http://dx.doi. org/10.3767/003158512X661462

Vánky, K. 2011['2012']. Smut fungi of the world. APS Press, St. Paul, Minnesota, USA. 
Vánky, K. 2013. Illustrated genera of smut fungi. $3^{\text {rd }}$ edn. APS Press, St. Paul, Minnesota, USA.

Vánky, K., Vánky, C. \& Denchev, C.M. 2011. Smut fungi in Africa - a checklist. - Mycologia Balcanica 8: 1-77.

Vorontsova, M.S. 2013. Variable morphology of the Madagascar endemic Aristida tenuissima (Poaceae: Aristidoideae) and the absence of Stipa (Poaceae: Pooideae, Stipeae) from Madagascar. - Phytotaxa 92: 55-58. http://dx.doi.org/10.11646/phytotaxa.92.2.4 